\title{
Management of Sequoiadendron giganteum and Sequoia sempervirens forests in the reserves of California - Considerations of ecology and conservation
}

\author{
David M. GRABER Biological Resources Division, United States Geological Survey, Sequoia \& Kings \\ Canyon Field Station, Three Rivers, California 93271 U.S.A.
}

\begin{abstract}
Giant sequoia (Sequoiadendron giganteum), also known as "Bigtree" and "Sierra Redwood," is entirely restricted to the Sierra Nevada mountain range in the State of California, while coast redwood (Sequoia sempervirens) is restricted to coastal northern California, extending northward slightly into the State of Oregon. Both charismatic species, members of the family Taxodiaceae, have served as important cultural icons in America, and both have played important roles in the history of nature conservation. The two species share important ecological similarities as well as significant differences; these ecological factors have become increasingly important in effecting their conservation, and in developing successful strategies for the long-term sustainable management of the forest communities in which they occur. The bulk of giant sequoia groves occur in reserves protected from logging, while only a small proportion of coast redwoods are similarly protected. For most of its history in the 20th century, conservation has been concerned with protecting uncut "old-growth" forest stands of giant trees. While this remains of great concern to the public, scientists and reserve managers have, in recent decades, extended their interest to what is known as "ecosystem management," which includes all aspects of the natural ecosystems in which coast redwoods and giant sequoias occur. For the first time, attempts are presently beginning--in those areas outside the national parks, state parks, and other reserves, to reconcile some levels of timber harvest with the long-term sustainable preservation of the character and biodiversity of giant sequoia and redwood forests.
\end{abstract}

Key Words: Sequoia / Sequoiadendron / conservation / ecology

\section{REDWOOD NATURAL HISTORY AND ECOLOGY}

The natural range of coast redwood is approximately 80,000 ha in northern coastal California and just into southern coastal Oregon. Fossil evidence of coast redwood (or something quite similar) extends back 20 million years in California. Redwood-like fossils have been found over much of the United States, Alaska, Greenland, France, and China, extending back to the middle or upper Jurassic Period. There is some evidence that the species has expanded northward during the past 10,000 years.

Coast redwood forest occurs nearly directly on the coast, and on the western slopes of the coastal mountains to an elevation of $600 \mathrm{~m}$, especially where fog is an important element of the climate, although individual trees range somewhat more broadly then this. Annual precipitation in redwooddominated forests ranges from $1,000 \mathrm{~mm}$ to well more than 2,000 $\mathrm{mm}$ per year. Temperatures rarely drop below freezing $\left(0^{\circ} \mathrm{C}\right)$. Common associates of coast redwood where it is dominant include bigleaf maple (Acer macrophyllum), Douglas-fir (Pseudotsuga menziesii), California bay (Umbellularia californica), madrone (Arbutus menziesii), and western azalea (Rhododendron occidentale).

Uncut coast redwood groves contain trees with an average age of 500 years, and a known 
maximum of at least 2,200 years. This species includes the tallest trees known, reaching heights of $112 \mathrm{~m}$ and diameters of up to $670 \mathrm{~cm}$. A number of animal species appear to be dependent upon these old-growth forests, and are rare or non-existent in younger stands of redwoods and their associates. Included among these old-growth-dependent species are birds that nest only in the larger diameter trees or standing dead snags, amphibians that require the shade and temperature- moderating conditions of the old-growth forests, or utilize large fallen logs as habitat, and some mammals as well.

Coast redwood is a climax species which is quite shade-tolerant as seedlings. It has a high moisture requirement and is frost sensitive. It possesses thick, shreddy bark which enables larger trees to withstand fire. However, natural fire frequency in most redwood groves ranges from 100 to 500 years. However, on some southern inland ridges the natural fire return-interval is 30-50 years, although redwoods appear not to be reproducing in these areas. Old individuals that have been exposed to repeated fires feature large, hollow scars at the base. Redwoods often occur on lowland alluvial flats. They do well so long are flooding is not too frequent or of long-duration. Alluvial flats, and other bare mineral soils (such as those produced by fire) provide the best substrate for seed germination, but in undisturbed forest, most successful redwood seedlings are found on fallen trees, so-called "nurse logs" which retain more moisture for the developing seedling than does the forest litter layer

A notable and peculiar feature of this conifer species is its ability to sprout from dormant buds in basal burl stem tissue. Because of its ability to re-sprout after being cut down or burned, the range of the coast redwood today, despite an extensive history of logging, is nearly identical to what it was prior to European settlement. In places where redwood were extensively logged, and in the southern portion of its range where fires have top-killed many trees, rings of trees are found that represent clones of the original "parent" tree.

\section{REDWOOD MANAGEMENT AND CONSERVATION}

Although the modern extent of coast redwood, about 80,000 ha, is nearly the same as it was when timber harvest began in earnest in 1850 , only 24,000 ha $(3 \%)$ remains as uncut old-growth forest. Logging of coast redwoods began in 1851 , shortly after the California gold rush. At first, only small logs were cut and floated to mills or dragged by oxen. After the railroads arrived in the $1870 \mathrm{~s}$, followed by the "steam donkey" in 1882, mature trees could be harvested. Although redwood is quite soft, its beauty and resistance to rot made it particularly desirable for siding on houses, and for decorative purposes. During the early decades of the 20th century, the giant redwoods were felled at an increasing rate. By the 1960s, selective removal of the most valuable trees on relatively flat terrain had been largely replaced by clear-cutting large areas of steep hillsides. Because of the high precipitation, this led to serious erosion problems, and the siltation of streams that were important as spawning grounds for anadromous fish, especially salmon.

The first preserve was created in 1902, when the State of California purchased what would become Big Basin State Park. Other relatively small holdings of old-growth and second growth redwood were acquired by the State of California over the next few decades with the assistance of a private conservation organization, the Save The Redwoods League, and converted to State Parks, but total reserve area was less than 8,000 ha of uncut forest. Because these small parks did not include entire watersheds, destructive logging practices above the parks continued to damage streams.

Beginning in the early 1960s, private conservation organizations began to seek public support for a national park that would protect an entire watershed. The National Geographic Society donated $\$ 64,000$ to the National Park Service to conduct a survey of the remaining old-growth redwoods. 
During the middle 1960s, negotiations took place among the government, conservation organizations, and the private timber companies which owned the lands. All the while, logging continued. After several years of negotiations and heated controversy, in 1968 Redwood National Park was created. Although 23,000 ha in size, half of this comprised existing state parks.

Although the world's tallest trees were now in the reserve, the upper portions of Redwood Creek were not, and intensive logging continued. Sedimentation and timber debris now damaged and further threatened not only the creek, but some of the lower stands of trees themselves. Once again the conservation groups sought further protection for what remained of the upper forest stands. The timber industry and local timber workers vehemently opposed any further expansion of the park. Finally, in 1978, an additional 19,000 ha of private forest land was acquired and added to Redwood National Park. Now more than 20,000 ha of old-growth redwoods were in public reserves, and another equal amount in protected second growth.

However, among the newly acquired lands, more than 14,000 ha had been logged, and much of that was denuded and continuing to erode, adding to the sediment in the streams. The mean annual erosion rate had risen to more than 3,000 tonnes per square kilometer. Consequently, the National Park Service undertook a massive job of rehabilitating the cut-over lands. As nothing like this had been attempted before, the Park Service experimented with different techniques for restoring the original terrain, restoring vegetation, and clearing streams. Logging roads and skip trails were "ripped" to reduce compaction, and then restored to their original grades. Straw and other materials were placed as mulch on bare, eroding slopes, and "wattles" of willow (Salix sp.) were planted along streambanks to intercept sediment. Seedling trees and shrubs were planted in some areas to accelerate recovery, with careful attention paid to using local sources for appropriate genetic stock. These efforts were extremely expensive, costing $\$ 33$ million over 15 years. Also, because they represented active engineering intervention with its own artificial effects on the landscape, these activities represented a significant alteration in the contemporary National Park Service philosophy of "letting nature take its course." Some of these efforts proved to be futile or even counter-productive, but a great deal learned about the management of the redwood forest ecosystem in the process. In the long run, the park hydrologist estimates that the rehabilitation efforts accelerated recovery 25 to 50 years over leaving the landscape to recover on its own.

Most recently, Redwood National Park has further edged into active manipulation of the redwood ecosystem. Some areas of second-growth forest, now several decades after clear-cutting, are impenetrable thickets of overcrowded small trees with very low species diversity. Left undisturbed, these stands would gradually thin themselves, and over several centuries develop the characteristics of more natural old-growth forests. The national park has entered into a contract with a regional logging company to thin these forest stands, so that late-successional characteristics will be developed more rapidly and the process of forest succession accelerated. In past years, conservation organizations would have opposed the manipulative aspects of such a treatment, and been suspicious of the park service entering into an agreement with a commercial timber enterprise. However, increasing awareness of the value of these kinds of forest management has now led to support for such activities when they are scientifically supported.

\section{GIANT SEQUOIA NATURAL HISTORY AND ECOLOGY}

The giant sequoia is found only in the Sierra Nevada mountain range of California. It occupies approximately $14,000 \mathrm{ha}$, ranging in elevation from $1,400 \mathrm{~m}$ to $2,300 \mathrm{~m}$, along a $400 \mathrm{~km}$ stretch of the 
range. Within its range, the species is highly localized, being restricted to about 75 community units commonly called "groves," ranging in size from a few individuals to about 600 ha and always intermixed with other conifer species. Recent palynological research has revealed that the present distribution of giant sequoia is quite recent: Only 5,000 years ago, the present location of the species was occupied by species characteristic of a colder, drier climate than present. Fossils of close relatives of Sequoiadendron giganteum have been found in a variety of locations, especially in western North America.

Although still falling within the range of climatic conditions customarily referred to as "Mediterranean," both temperature and precipitation are significantly more extreme in the range of the giant sequoia than for the coast redwood. Precipitation ranges from $460 \mathrm{~mm}$ to $1,500 \mathrm{~mm}$, the mean being about $1,100 \mathrm{~mm}$. However, nearly all of this precipitation occurs between November and April, most of it as snow. Often there is no precipitation for two months or more during the summer. Temperatures typically range between $-12{ }^{\circ} \mathrm{C}$ and $32{ }^{\circ} \mathrm{C}$, with extremes of $-17^{\circ} \mathrm{C}$ and $38{ }^{\circ} \mathrm{C}$, respectively. Common co-dominant associates of giant sequoia include white fir (Abies concolor), sugar pine (Pinus lambertiana), and ponderosa pine (Pinus ponderosa), but several other species of conifer also occur in some locales. Giant sequoias appear to occupy micro-sites that are both moister and contain deeper soils than typical for these mixed-conifer forests as a whole, but they are nonetheless far more drought-tolerant than coast redwood.

The oldest living giant sequoias appear to be approximately 2,500 years of age, although annular ring counts of up to 3,200 have been claimed from stumps. Groves typically contain a broad range of ages; trees more than 1,000 years old are not uncommon. Giant sequoias grow to larger diameters, to perhaps $1,200 \mathrm{~cm}$, but not so tall, up to $94 \mathrm{~m}$, as coast redwoods. Although giant sequoia forests often contain many of the physical attributes of more mesic old-growth forests elsewhere, including many large trees, extensive canopies, and large standing dead snags and logs, giant sequoia forests are distinctively different because of the presence of frequent fire.

Unlike coast redwood, giant sequoia is a shade-intolerant, seral species that, under natural conditions, typically requires fire to provide bare mineral soil and a break in the canopy for its establishment as a successful seedling, and frequent low-intensity fires thereafter which permit it to compete with more shade-tolerant competitors. Once mature, the thick, fibrous bark of giant sequoias permits them to survive fires of moderate intensity. However, nearly all trees more than $300 \mathrm{~cm}$ in diameter also possess fire scars that comprise a substantial portion of their circumferences. These fire scars are occasionally so cavernous that they have served as the hibernation dens of black bears (Ursus americanus), or living quarters for human beings.

\section{GIANT SEQUOIA MANAGEMENT AND CONSERVATION}

The giant sequoia was first reported by Euro-Americans in the 1830 s, when the Sierra Nevada range was still quite wild and occupied by Native American (Indian) tribes. After that, a number of people visited the trees and reported their great girth and height. The bark from one great specimen was carefully removed and reconstructed for display in the Crystal Palace at Sydenham, England. This sort of activity was repeated several times during the middle and late $1800 \mathrm{~s}$.

Beginning in the 1850s, active logging began in some of the giant sequoia groves. The wood of this species is not only soft, but brittle at maturity, and the great trees usually shattered upon striking the ground, wasting most of the wood. As this logging activity, there grew increasing public objection to the felling of the largest trees, and the terrible wastage that took place in logging this species. When the logging of mature giant sequoias finally ceased, about one-third had been felled. 
In 1864, the United States government set aside the Mariposa Grove in what is now Yosemite National Park, and deeded it to the State of California. To the south, public concern that logging activity threatened the security of the water supply led to the creation of Sequoia, General Grant (now part of Kings Canyon), and Yosemite National Parks in 1890. All three included substantial groves of giant sequoias.

In the years that followed, lands containing giant sequoia groves were added to national and state parks, and most of the remainder became part of national forests, at which logging the monarch trees effectively ceased. Today, $68 \%$ of sequoias are in national parks, $21 \%$ in national forests, and $3 \%$ on other public lands. There has been no logging of the larger giant sequoias on public or private lands for many decades.

Fire was common in the lower and middle elevations of the Sierra Nevada until the late 1800s. Not only did lightning start many fires, but American Indians and later settlers also set fires to reduce brush and improve grazing land. However, with the establishment of national parks and national forests on the bulk of land in the Sierra Nevada, intentional ignitions virtually ceased, and instead fire suppression became the order of the day. By the 1920s, fire suppression had become a highly effective program.

Beginning in the 1950 s, some forest scientists noticed that forest composition was changing in the Sierra Nevada, especially in the mixed-conifer forests that include giant sequoia, and that fuels on the forest floor were accumulating to unprecedented levels. The density of shade-tolerant species, such as white fir, was steadily increasing. Furthermore, there was no reproduction of giant sequoia.

Scientists studying fire dynamics in the early 1960s suggested that the accumulation of living and dead fuels in the sequoia groves was so substantial that if a forest fire did start, its intensity would lead to canopy fire and the destruction of the giant sequoias. They argued that carefully-controlled ground fires were needed to consume excess fuels and to protect the monarch giant sequoias. During the late 1960s, scientists from the University of California and the National Park Service cooperated in experimental burning in giant sequoia groves in and adjacent to Kings Canyon National Park. In the decades that followed, to the present time, the National Park Service endeavored to conduct "prescribed management fires" (controlled burns) in the giant sequoia groves of Yosemite, Kings Canyon, and Sequoia National Parks. Because of the tremendous fuel accumulations over the past years of fire suppression, and public fear of the fires escaping or destroying the giant sequoias, great care was taken to keep these controlled fires at low intensity. As a result, although litter on the forest floor was largely consumed, most trees greater than $15 \mathrm{~cm}$ diameter survived the fires, while the remainder persisted as charred snags after the fire, contributing to the load of dead fuels.

Giant sequoias are excellent recorders of past fires. Careful study of sections of dead trees up to 1,500 years old revealed that in the past, fires burned through the groves as often as every 2-10 years. Such a fire frequency would have produced a far more open forest than presently exists in nearly all giant sequoia groves today. Although it is the stated intention of the National Park Service to restore both "natural processes" (i.e. fire) and "natural structure" to the giant sequoia forests, this goal is presently only a wish. Economic, political, social, and environmental constraints have prevented the Park Service from even approaching either natural fire frequency or natural structure in its giant sequoia groves.

Other recent research has revealed that although even low-intensity fire produced the bare mineral soil necessary for giant sequoia seed germination, unless the canopy has been opened by fire or other factors, the shade-intolerant seedlings do not survive. Only where sufficiently high intensities of fire have been achieved which have produced gaps in the forest canopy have giant sequoia seedlings survived and grown to saplings.

In the sequoia groves of the national forests, where commercial timber harvest is practiced and -until recently--fires were routinely suppressed everywhere, different courses of action have been at 
work. In some groves, the forest service removed tree species other than giant sequoia as part of commercial timber harvest. Practiced correctly, this thinning serves some of the same functions as prescribed fire. It opens the canopy, bringing light to shade-intolerant young giant sequoias, and reduces fuels. However, by itself it does not produce the bare-mineral soil required for successful giant sequoia germination. In recent years, conservation organizations have strenuously objected to any commercial forest activities in the giant sequoia groves and their immediate surroundings. This has led to a cessation of such activities at the present time.

Present grove conditions are these: About half of all giant groves are still protected from both fire and logging. In these groves, the risk of a high-intensity, stand-destroying wildfire is greatest. Giant sequoia reproduction has effectively ceased as well. About $18 \%$ of groves have been treated with prescribed fire. These fires have reduced surface fuel loads to about $8 \%$ of their preburn levels of 190 tonnes/ha. However, within less than a decade, surface fuels had returned to more than half their original levels. And prescribed fires of the 1980s and 1990s, of generally lower intensity, were significantly less effective than this. Also, after only one fire, mortality of small trees has led to increases in the mass of woody fuels.

About $23 \%$ of giant sequoia groves were logged prior to 1980 . Changes in structure and composition in these groves has been very complex, depending on local conditions. In groves where the monarch giant sequoias were logged, there are many patches of reproduction, including sequoias now a century in age. But it will be at least another century before old-growth characteristics are reestablished in these logged groves. Of the groves logged since 1980 (about $6 \%$ of all groves), in which species other than giant sequoias were removed, a complex mixture of conditions presently obtains. In some cases, there are presently open stands of large giant sequoias as the only overstory, with an understory of shrub species and seedling trees. Although these managed groves meet some of the criteria for restoring natural giant sequoia grove ecology, large segments of the public have found them esthetically unacceptable. On the other hand, doing nothing while suppressing fire will lead for a further deterioration of natural conditions.

At the present time, public land managers, ecologists, conservation organizations, and the timber industry are engaged in an exploration of alternative ways to successfully manage giant sequoia forests. This will require defining specific restoration goals for the differing agencies, determining the "natural range of variation" of the sequoia forests themselves, determining the possibility and practicality of meeting restoration objectives, and choosing the tools, such as prescribed fire and logging, and approach to achieving those objectives.

\section{Graber, David M.カリフォルニアにおける森林保護区のセコイアオスギ林とセ コイアメスギ林の管理}

ビッグツリーまたはシエラレッドウッドとも呼ばれているセコイアオスギは, カリフォルニア州のシエラ ネヴァダ山脈にその分布が限られており, セコイアメスギ（コーストレッドウッド）はカリフォルニア沿 岸北部からわずかに北のオレゴン州に分布が伸びている。両種ともスギ科の植物で, その威容から米国で は重要な文化的偶像となってきたと同時に，自然保護の歴史のなかで重要な役割を果たしてきた。両種は 生態学的にはっきりとした違いがあるだけでなく, よく類似している面がある。従って, これらの生態学 的要因を把握することは, 両種の保護と両種が生育している森林群落を長期に亘って維持管理する戦略を 考えるためにますます重要になつてきた。現在, 大面積のセコイアオスギ林が伐採から護られて存在し, 一方セコイアメスギ林は小面積しか保護されていない。二十世紀の殆どの期間ではセコイアオスギ林の保 全は，その伐採されていない「過熟林」を保護することであった。しかし，この数十年間国民，科学者， 保護管理官の主な関心は，セコイアオスギとセコイアメスギが生育している自然生態系のすべてを含む 「生態系の管理」へと移っていった。その手始めとして, 国立公園, 州立公園, その他の保護地以外の森林 で，セコイアオスギ林及びセコイアメスギ林での集材をある程度のレベルに抑えることと，その森林の特 徵と生物多様性を長期に亘って維持することと両立させる試みが今始まっている。 